\title{
PENGARUH RETURN ON ASSET TERHADAP NILAI PERUSAHAAN DENGAN KEPEMILIKAN MANAJERIAL SEBAGAI VARIABEL MODERASI
}

\author{
Krisnando \\ Sekolah Tinggi Ilmu Ekonomi Indonesia \\ Jl. Kayu Jati Raya No. 11A, Rawamangun - Jakarta 13220, Indonesia \\ krisnando@gmail.com
}

\begin{abstract}
This study is aimed to test the effect of return on assets on firm value with managerial ownership as a moderating variable in manufacturing companies that listed in Indonesia Stock Exchange (BEI) with the research period from 2016 to 2017.This research uses associative quantitative approach, which is measured using of multiple linear regression based method use Eviews 9. The population of this study is manufacturing companies listed on the Indonesia Stock Exchange (BEI) in 2016 up to 2017. Sample was determined by purposive sampling method, and get 61 manufacturing companies. So, total observation in this research are 122 observations. The data used in this study are secondary data. Data collected techniques using the documentation method through the official website of IDX: www.idx.co.id, hypothesis testing are using $t$ test.The results of the study prove that (1) Return on Assets has a significant positive effect on Company Value which is proxied by Tobin's Q on manufacturing companies listed on the IDX for the period 2016-2017, (2) Managerial ownership does not significantly influence or weaken the relationship between Return on Assets with Company Value which is proxied by Tobin's Q for manufacturing companies listed on the Indonesia Stock Exchange for the period of 2016-2017
\end{abstract}

Keywords: Return on Assets, Tobin's Q, and Managerial Ownership

\section{PENDAHULUAN}

\subsection{Latar Belakang Masalah}

Sejalan dengan perkembangan dunia usaha persaingan dalam bisnis saat ini tidak bisa dihindari dan semakin kompetitif, sehingga setiap perusahaan harus bersaing secara ketat. Perusahaan harus mampu untuk meningkatkan kinerja dalam mencapai 
tujuan. Tujuan ini tidak hanya merupakan kepentingan bagi para pemegang saham semata, namun juga memberikan manfaat yang terbaik bagi masyarakat di lingkungan perusahaan.

Menurut Undang-Undang no.3 Tahun 1982 dalam pasal 1 huruf (b) UndangUndang Perusahaan (UWDP), perusahaan adalah setiap bentuk usaha yang dijalankan yang bersifat kelanjutan dan didirikan, bekerja dan berkedudukan di wilayah Negara Republik Indonesia untuk mendapat profit atau laba.

Nilai perusahaan adalah gambaran mengenai keadaan umum dalam suatu perusahaan. Perusahaan dinilai baik apabila perusahaan menyajikan laporan keuangan dengan baik. Laporan keuangan menunjukkan bagaimana kondisi perusahaan saat ini dan prospek di masa depan. Maka dari itu pengelolaan laporan keuangan harus dilakukan dengan baik untuk memberikan dividen kepada investor, meningkatkan pertumbuhan, dan mempertahankan kelangsungan kehidupan perusahaan.

Salah satu indikator yang dapat digunakan untuk mengukur nilai perusahaan adalah dengan Tobin's $Q$ ratio. Tobin's $Q$ dihitung dengan membandingkan rasio nilai pasar saham perusahaan dengan nilai buku ekuitas perusahaan. Rasio ini menunjukkan estimasi pasar keuangan saat ini tentang nilai hasil pengembalian dari setiap dolar investasi inkremental. Tobin's $Q$ merupakan ukuran tentang seberapa efektif manajemen memanfaatkan sumber-sumber daya ekonomis dan kekuasaannya.

Beberapa penelitian sebelumnya tentang ROA terhadap nilai perusahaan yaitu, (Imron, Hidayat, \& Alliyah, 2013), (Hermuningsih, 2013), (Kusumawati \& Rosady, 2018), menyatakan bahwa variabel kinerja keuangan (ROA) berpengaruh positif signifikan terhadap nilai perusahaan. Hasil penelitian ini didukung oleh beberapa peneliti lainnya yaitu (Sari, Mardani, \& Salim, 2018) yang juga menyatakan bahwa Return on Asset terbukti berpengaruh positif signifikan terhadap nilai perusahaan.

Namun, hasil yang berbeda diperoleh oleh (Saragih, 2018), hasil penelitian menunjukkan profitabilitas memiliki pengaruh negatif yang signifikan terhadap nilai perusahaan. Hasil pengolahan data variabel profitabilitas diukur dengan Return On Asset (ROA). Hasil penelitian ini didukung oleh (Erdianty \& Bintoro, 2014) yang menyatakan bahwa Return On Asset (ROA) tidak berpengaruh signifikan terhadap nilai perusahaan. 
Tata kelola perusahaan yang baik atau Good Corporate Governance (GCG) hingga saat ini terus dikembangkan oleh pemerintah agar dapat dikembangkan oleh dunia usaha. Konsep ini dianggap sangat penting untuk diterapkan agar perusahaan di Indonesia dapat kuat dalam menghadapi krisis. Undang-Undang No.40 Tahun 2017 adalah pembaharuan tentang konsep pengelolaan perseroan dengan tujuan untuk mendukung implementasi GCG. Adanya benturan kepentingan (conflict of interest) antara manajer dan shareholders dapat menurunkan kinerja perusahaan dan menghilangkan minat investor untuk berinvestasi karena hilangnya kepercayaan investor pada kemampuan perusahan terhadap return dari investasi yang telah mereka tanam. Sehingga dengan dua kepentingan yang saling tarik menarik ini, diharapkan pada pengelolaan perseroan yang baik dapat mengakses kepentingan kedua belah pihak.

Berdasarkan uraian tersebut penulis tertarik untuk melakukan penelitian dengan mengambil judul "PENGARUH RETURN ON ASSET TERHADAP NILAI PERUSAHAAN DENGAN KEPEMILIKAN MANAJERIAL SEBAGAI VARIABEL MODERASI" (Studi Empiris pada Perusahaan Manufaktur yang terdaftar di Bursa Efek Indonesia Periode 2016-2017).

\section{KAJIAN LITERATUR}

\subsection{Review Hasil-Hasil Penelitian Terdahulu}

Penelitian yang dilakukan oleh Imron, Hidayat, \& Alliyah pada tahun 2013 dengan teknik sampling yang digunakan adalah purposive sampling dengan jumlah sampel sebanyak 28 perusahaan dan teknik analisis data yaitu analisis regresi moderasi. Dalam penelitian ini menggunakan variabel independen yaitu kinerja keuangan yang diproksikan dengan ROA sedangkan variabel dependen nilai perusahaan yang diproksikan dengan PBV. Variabel moderasi yang digunakan yaitu pengungkapan CSR dan GCG. Hasil penelitian yang diperoleh dalam penelitian ini yaitu variabel kinerja keuangan (ROA) berpengaruh positif signifikan terhadap nilai perusahaan dan GCG mampu memperkuat hubungan antara kinerja keuangan dan nilai perusahaan.

Kemudian penelitian yang dilakukan oleh Hermuningsih pada tahun 2013 yang dilakukan melalui pendekatan Structural Equation Modeling (SEM) yaitu memodelkan secara eksplisit kesalahan pengukuran, kemudian mencar estimator yang tidak bias untuk hubungan antar variabel. Hasil penelitian yang diperoleh dalam penelitian ini 
yaitu variabel profitabilitas (ROA \& ROE) berpengaruh positif dan signifikan terhadap nilai perusahaan.

Penelitian selanjutnya yang dilakukan Kusumawati \& Rosady pada tahun 2018 dengan purposive sampling dengan jumlah sampel sebanyak 96 sampel. Hasil penelitian yang diperoleh pada penelitian ini yaitu profitabilitas (ROA) berpengaruh positif dan signifikan terhadap nilai perusahaan dan profitabilitas (ROA) yang dimoderasi kepemilikan manajerial berpengaruh negatif dan signifikan terhadap nilai perusahaan.

Penelitian yang dilakukan oleh Sari, Mardani, \& Salim pada tahun 2016 yang diperoleh pada penelitian ini yaitu ROA dapat berpengaruh positif signifikan terhadap nilai perusahaan dan GCG dapat memoderasi hubungan antara ROA dengan nilai perusahaan.

Penelitian yang dilakukan oleh Fahlenbrach \& Stulz pada tahun 2009 yang pada perusahaan-perusahaan di Amerika menemukan bahwa manajer lebih cenderung mengurangi kepemilkan mereka secara signifikan ketika perusahaan mereka berkinerja baik dan lebih banyak kemungkinan akan meningkatkan kepemilikan mereka ketika perusahaan mereka menjadi terhambat secara finansial. Saat mengendalikan pengembalian saham sebelumnya, peneliti menemukan bahwa peningkatan besar dalam lepemilikan manajerial meningkatkan Tobin's Q. Hasil ini didorong oleh peningkatan saham yang dipegang oleh petugas, sementara kenaikan saham yang dipegang oleh direksi tampaknya tidak terkait dengan perubahan nilai perusahaan. Tidak ada bukti bahwa penurunan besar dalam kepemilikan berdampak buruk pada nilai perusahaan.

\subsection{Kinerja Keuangan}

Menurut Mulyadi (2007 : 2) kinerja keuangan adalah penentuan efektifitas operasional suatu organisasi dan karyawan secara periodik berdasarkan sasaran, standar, dan kriteria yang telah ditetapkan. Sedangkan menurut Institusi Akuntansi Indonesia (IAI) kinerja keuangan adalah kemampuan perusahaan dalam mengelola dan mengendalikan sumber daya yang dimiliki.

Kinerja perusahaan dapat diukur dengan menggunakan rasio keuangan (Prasinta, 2012). Investor melakukan penanaman modal salah satunya melihat rasio profitabilitas (Prasinta, 2012). Rasio profitabilitas yang digunakan dalam penelitian ini adalah Return On Asset (ROA) karena dapat memberikan gambaran tingkat pengembalian keuntungan yang dapat diperoleh investor atas investasinya (Prasinta, 2012). Selain itu dengan 
ROA, investor dapat melihat bagaimana perusahaan mengoptimalkan penggunaan asetnya untuk dapat memaksimalkan laba yang juga menjadi tujuan GCG untuk menggunakan aset dengan efisien dan optimal (OECD, 2004).

\subsection{Nilai perusahaan}

Menurut Sudjoko \& Soebiantoro dalam Randy dan Juniarti (2013), nilai perusahaan merupakan persepsi investor terhadap perusahaan yang sering dikaitkan dengan harga saham. Oleh karena itu, nilai perusahaan akan tercermin dari harga sahamnya. Nilai perusahaan yang dibentuk melalui indikator nilai pasar sangat dipengaruhi oleh peluang-peluang investasi. Adanya peluang investasi dapat memberikan sinyal positif (signal theory) tentang pertumbuhan perusahaan di masa yang akan datang sehingga dapat meningkatkan nilai perusahaan.

Menurut Lang dalam Sudiatno \& Puspita Sari (2010), Tobin's $Q$ adalah indikator untuk mengukur kinerja perusahaan, khusunya tentang nilai perusahaan, yang menunjukkan suatu performa manajemen dalam mengelola aktiva perusahaan. Nilai Tobin's $Q$ menggambarkan suatu kondisi peluang investasi yang dimiliki perusahaan atau potensi pertumbuhan nilai pasar saham (market value of all out standing stock) dibandingkan dengan nilai seluruh modal yang ditempatkan dalam aktiva produksi (replacement value all production capacity), maka Tobin's $Q$ dapat digunakan untuk mengukur kinerja perusahan, dari sisi potensi nilai pasar suatu perusahaan.

\section{Good Corporate Governance}

Menurut Forum For Corporate Governance in Indonesia (FCGI) corporate governance adalah seperangkat peraturan yang menetapkan hubungan antara pemegang saham, pengurus, pihak kreditur, pemerintah, karyawan serta para pemegang kepentingan internal dan eksternal lainnya sehubungan dengan hah-hak dan kewajiban mereka, atau dengan kata lain sistem yang mengarahkan dan mengendalikan perusahaan.

\subsection{Kepemilikan Manajerial}

Kepemilikan manajerial merupakan salah satu elemen GCG yang berpengaruh secara intensif bagi manjemen untuk melaksanakan kepentingan terbaik dari pemegang saham sebagai pemilik saham. Struktur kepemilikan pada perusahaan memiliki dampak yang berbeda tentang bagaimana tindakan manajemen dalam mengambil resiko (Chun S, 2017). Menurut Darmawati \&Rahayu (2004), inti dari hubungan keagenan ini adalah 
pemisahan antara pengendalian selaku pihak agent da kepemilikan selaku pihak principal. Investor mempunyai harapan bahwa kekayaan investor dan kemakmuran investor akan bertambah dengan mendelegasikan wewenang pengelolaan pada manajer tersebut. Kepemilikan manajerial bisa diukur dari presentase sahan yang dimiliki manajamen. Kepemilikan manajerial cukup kuat dalam melaksanakan Good Corporate Governance, karena berperan penting dalam penerapan Good Corporate Governance dengan prinsip-prinsip yang sudah ada (Erdianty \& Bintoro, 2014).

\subsection{Teori Sinyal (Signaling Theory)}

Prastyaningrum (2008), dalam Shanty (2014) teori sinyal (signaling theory) menjelaskan mengapa perusahaan memiliki dorongan untuk memberikan laporan keuangan kepada pihak eksternal. Dorongan perusahaan untuk memberikan informasi adalah karena asimetri informasi antara manajemen perusahaan dan pihak luar (investor).

Sebagaimana yang dijelaskan Prastyaningrum (2008) dalam Shanty (2014), asimetri informasi dapat terjadi apabila salah satu pihak memiliki sinyal informasi yang lebih lengkap dari pihak lain. Asimetri informasi terjadi jika manajemen tidak menyampaikan semua informasi yang diperoleh secara penuh sehingga mempengaruhi nilai perusahaan yang terekleksi pada perubahan harga saham karena pasar akan merespon informasi yang ada sebagai sinyal.

Teori sinyal mengemukakan tentang bagaimana seharusnya sebuah perusahaan memberikan sinyal kepada pengguna laporan keuangan. Sinyal itu berupa informasi mengenai apa yang sudah dilakukan oleh manajemen untuk merealisasikan keinginan pemilik. Sinyal dapat berupa promosi atau informasi lain yang menyatakan bahwa perusahaan tersebut lebih baik daripada perusahaan lain Mustafa \& Handayani (2014).

\subsection{Teori Agensi (Principal Agency Theory)}

Menurut teori keagenan, ketika ada pemisahan antara pemilikan dengan pengelolaan perusahaan akan dapat memicu munculnya konflik keagenan. Konflik keagenan ini timbul ketika terdapat perbedaan kepentingan antara prinsipal dengan agen untuk memaksakan utilitasnya sendiri. Adanya perbedaan kepentingan diantara manajemen dan pemilik perusahaan mengakibatkan manajemen berperilaku curang sehingga pemilik perusahaan mengalami kerugian. Untuk itu diperlukan cara 
pengendalian yang dapat mensejajarkan perbedaan kepentingan antara manajemen dengan pemegang saham. Laporan keuangan dapat mencerminkan adanya konflik antara pemilik dengan manajer dalam beberapa hal yang tergambar dalam teori keagenan. Diperlukan pelaporan secara rutin sebagai cara pemilik memonitor kontrak dengan manajer. Konflik kepentingan semakin meningkat ketika prinsipal tidak dapat dengan mudah mengawasi perilaku agen. Cara pengendalian yang terbaik dilakukan adalah dengan kepemilkan saham oleh pihak manajerial (Komang \& Wirawati, 2013).

\subsection{Perumusan Hipotesis}

\section{Pengaruh Return On Asset terhadap nilai perusahaan}

Teori yang dikemukakan oleh Modigliami dan Miller menyatakan bahwa nilai perusahaan ditentukan oleh earnings power dari aset perusahaan. Hasil positif menunjukkan bahwa semakin tinggi nilai earnings power semakin efisien perputaran aset dan atau semakin tinggi profit earnings yang diperoleh perusahaan. Hal ini akan berdampak pada nilai perusahaan.

Menurut Mardiyanto (2009 : 196) ROA adalah rasio yang digunakan untuk mengukur kemampuan perusahaan dalam menghasilkan laba yang berasal dari aktivitas investasi. Semakin besar ROA, semakin besar pula tingkat keuntungan yang dicapai oleh perusahaan tersebut dan semakin baik pula posisi perusahaan tersebut dari segi penggunaan aset. Peningkatan daya tarik perusahaan menjadikan perusahaan tersebut semakin diminati investor, karena tingkat pengembalian akan semakin besar. Hal ini juga akan berdampak terhadap harga saham dari perusahaan tersebut sehingga nilai perusahaan akan semakin baik pula dengan adanya peningkatan ROA.

\section{H1 : Return on asset berpengaruh positif signifikan terhadap nilai perusahaan}

\section{Pengaruh kepemilikan manajerial terhadap hubungan antara return on asset dengan nilai perusahaan}

Kepemilikan manajerial merupakan salah satu elemen GCG yang berpengaruh secara intensif bagi manajemen untuk melaksanakan kepentingan terbaik dari pemegang saham sebagai pemilik saham. Kepemilikan saham adalah presentase kepemilikan saham yan dimiliki oleh manejemn yaitu direksi, manajer, dan dewan komisaris yang secara aktif ikut serta dalam pengambilan keputusan perusahaan. "Kepemilikan 
manajerial akan mendorong manajemen untuk meningkatkan kinerja perusahaan, keran mereka juga memiliki perusahaan” (Sujoko dan Soebiantoro, 2007 : 47).

Kepemilikan manajerial merupakan salah satu dari struktur kepemilikan saham yang dapat mempengaruhi insentif bagi manajemen untuk melaksanakan kepentingan terbaik dari pemegang saham. Semakin tinggi kepemilikan manajerial diharapkan pihak manejemen akan berusaha semaksimal mungkin untuk kepentingan para pemegang saham (Hermawati dalam Sari, 2015 : 7). Semakin besar proporsi kepemilikan manajemen maka manajemen cenderung berusaha lebih giat untuk kepentingan pemegang saham untuk meningkatkan nilai perusahaan (Yana dalam Perdana dan Raharja, 2014 : 2-3).

\section{H2 : Kepemilikan manajerial memperkuat hubungan antara Return On Asset terhadap nilai perusahaan}

\subsection{Kerangka Konseptual Penelitian}

Penelitian ini akan menguji pengaruh Return On Asset terhadap nilai perusahaan dengan kepemilikan manajerial sebagai variabel moderasi pada perusahaan manufakturyang terdaftar di Bursa Efek Indonesia pada periode 2016-2017 di Indonesia. Model kerangka pemikiran teoritis dalam penelitian ini dapat dilihat pada gambar 2.1

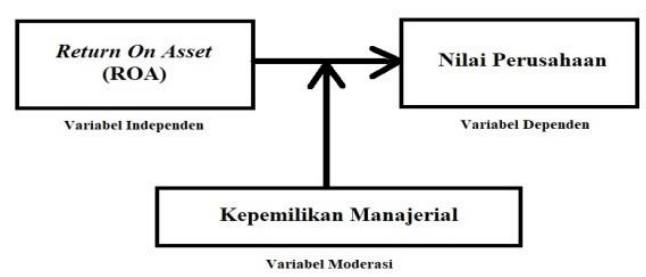

Gambar 2.1

Kerangka Konseptual Penelitian Pengaruh Return On Asset Terhadap Nilai Perusahaan dengan Kepemilikan Manajerial sebagai Variabel Pemoderasi.

Sesuai dengan gambar diatas, maka dalam penelitian ini variabel independen ROA akan diuji pengaruhnya terhadap variabel dependen nilai perusahaan dan akan dimoderasi oleh kepemilikan manajerial. 


\section{METODE PENELITIAN}

\subsection{Strategi Penelitian}

Strategi penelitian yang digunakan dalam penelitian ini adalah strategi asosiatif. Penelitian asosiatif adalah penelitian yang mengkaji hubungan antara variabel bebas (independen variabel) dengan variabel terikat (dependen variabel). Tujuan dalam penelitian ini yaitu untuk mengkaji hipotesis penelitian dan hubungan sebab-akibat antara 2 (dua) variabel atau lebih yang terdiri dari vaiabel bebas sebagai variabel yang mempengaruhi dan variabel terikat sebagai variabel yang dipengaruhi.

Metode yang digunakan dalam penelitian ini adalah metode kuantitatif. Menurut Sugiyono (2017 : 7) metode kuantitatif dapat diartikan sebagai metode pasitivistik karena berlandasan pada filsavat positivisme. Metode ini sebagai metode ilmiah/scientific karena telah memenuhi kaidah-kaidah ilmiah yaitu konkrit/empiris, objektif, terukur, rasional, dan sistematis. Metode ini juga disebut dengan metode discovery, karena dengan metode ini ditemukan dan dikembangkan berbagai iptek baru. Metode ini disebut metode kuantitatif karena data dan penelitian berupa angka-angka dan analisis menggunakan statistik. Oleh karena itu, peneliti akan meneliti tentang pengaruh Return On Asset terhadap nilai perusahaan dengan kepemilikan manajerial sebagai variabel moderasi pada perusahaan manufaktur di Indonesia periode 2016-2017.

\subsection{Populasi dan Sampel}

\section{Populasi Penelitian}

Sugiyono (2017 : 80) mengatakan dalam penelitian kuantitatif populasi adalah wilayah generalisasi yang terdiri atas objek atau subjek yang mempunyai kuantitas dan karakteristik tertentu yang ditetapkan oleh peneliti untuk dipelajari dan kemudian ditarik kesimpulannya. Populasi dalam penelitian ini adalah perusahaan manufaktur yang terdaftar di Bursa Efek Indonesia (BEI) dengan periode penelitian 2016-2017. Hal ini untuk mengetahui pengaruh Return On Asset terhadap nilai perusahaan dengan kepemilikan manajerial sebagai variabel moderasi pada perusahan manufaktur selama tahun 2016 sampai dengan tahun 2017. Alasan pemilihan objek penelitian pada kelompok industri mnufaktur adalah bahwa industri manufaktur merupakan kelompok 
terbesar dibandingkan dengan kelompok industri yang lain, semakin besar objek yang diamati maka diharapkan semakin tepat hasil kajian. Total perusahaan yang terdaftar adalah 143 perusahaan.

\subsection{Sampel Penelitian}

Sugiyono (2017 : 81) mengatakan dalam penelitian kuantitatif sampel adalah bagian dari jumlah dan karakteristik yang dimiliki oleh populasi tersebut. Adapun teknik pengambilan sampel dalam penelitian ini adalah Nonprobability Sampling yaitu teknik pengambilan sampel yag tidak memberi peluang/kesempatan yang sama bagi setiap unsur atau anggota populasi untuk dipilih menjadi anggota sampel (Sugiyono, 2017 : 84). Teknik Nonprobability Sampling yang digunakan adalah purposive sampling. Purposive Sampling yaitu cara pengambilan sampel yang didasarkan pada pertimbangan-pertimbangan tertentu. Tujuannya adalah untuk mendapatkan sampel yang sesuai dengan kriteria yag ditentukan (Sanusi, 2014 : 95). Adapun kriteria yang digunakan dalam penelitian ini adalah sebagai berikut :

1. Perusahaan sampel terfaftar di Bursa Efek Indonesia (BEI) tahun 2016-2017 dalam kelompok manufaktur.

2. Perusahaan menerbitkan laporan tahunan (annual report) dan data keuangan yang lengkap selama tahun penelitian.

3. Perusahaan tidak mengalami kerugian selama tahun pengamatan karena angka laba negatif menjadi tidak bermakna.

4. Perusahaan memiliki data keuangan yang berkaitan dengan variabel penelitian secara lengkap.

5. Perusahaan menggunakan satuan nilai rupiah dalam laporan keuangannya.

\subsection{Data dan Metode Pengumpulan Data}

Data yang dikumpulkan dari penelitian ini adalah data sekunder. Data sekunder adalah data yang mengacu pada informasi yang dikumpulkuan dari sumber yang telah ada. Sumber data sekunder adalah catatan atau dokumentasi perusahaan, publikasi pemerintah, analisis industri oleh media, situs Web, internet dan seterusnya (Uma Sekaran, 2011).

Metode pengumpulan data dalam penelitian ini menggunakan metode dokumentasi. Metode dokumentasi adalah pengumpulan data dengan cara mencatat 
dokumen yang berhubungan dengan penelitian ini (Sugiyono, 2010). Dokumen tersebut berupa laporan keuangan perusahaan manufaktur yang bersumber dari website http://www.idx.co.id. Data untuk masing-masing variabel independen, variabel dependen, dan variabel moderasi diperoleh dengan cara mengunduh dan menelaah laporan keuangan tahunan masing-masing perusahaan yang terdaftar dalam BEI periode 2016-2017.

\subsection{Operasionalisasi Variabel}

Penelitian ini melibatkan variabel yang terdiri dari satu variabel bebas (independen), satu variabel terikat (dependen), dan satu variabel moderasi. Pengertian variabel menurut Sugiyono (2017 : 38) adalah segala sesuatu yang berbentuk apa saja yang ditetapkan oleh peneliti untuk memperlajari sehingga diperoleh informasi tentang hasil tersebut, kemudian ditarik kesimpulannya. Variabel independen dalam penelitian ini adalah Return On Asset. Variabel dependennya adalah nilai perusahaan. Variabel moderasinya adalah kepemilikan manajerial.

\subsection{Variabel Independen $(X)$}

Variabel independen sering disebut sebagai variabel stimulus, predictor, antecedent. Menurut Sugiyono (2017 : 39) variabel independen atau variabel bebas adalah variabel yang mempengaruhi atau yang menjadi sebab perubahannya atau timbulnya variabel dependen (terikat). Variabel independen dalam penelitian ini adalah Return On Asset (ROA). Pada penelitian ini, ROA dihitung dengan menggunakan rumus sebagai berikut :

$$
R O A=\frac{\text { Laba Setelah Pajak }}{\text { Total Aset }}
$$

\subsection{Variabel Dependen (Y)}

Variabel dependen sering disebut sebagai variabel output, kriteria, dan konsekuen. Sugiyono (2017 : 39) menjelaskan variabel dependen atau variabel terikat merupakan variabel yang dipengaruhi atau yang menjadi akibat karena adanya variabel bebas. Maka variabel dependen dari penelitian ini adalah nilai perusahaan yang diukur dengan menggunakan Tobin's $Q$. Pada penelitian ini Tobin's $Q$ dihitung dengan menggunakan rumus sebagai berikut :

$$
\text { Tobin's }^{\prime}=\frac{(E M V+D)}{(E B V+D)}
$$


Keterangan :

Tobin's $Q$

$=$ Nilai perusahaan

EMV (Nilai Pasar Ekuitas) = Closing Price x Jumlah saham beredar

$\mathrm{D}$

$=$ Nilai buku dari total hutang

EBV

= Nilai buku dari total aktiva

\subsection{Variabel Moderasi $(Z)$}

Variabel moderasi dari penelitian ini adalah kepemilikan manajerial. Kepemilikan manajerial adalah persentase jumlah saham yang dimiliki manajemen dari seluruh jumlah saham perusahaan yang dikelola (Boediono : 2005). Pada penelitian ini kepemilikan manajerial dihitung dengan menggunakan rumus sebagai berikut :

$$
K M=\frac{\text { kepemilikan saham oleh manajer, direktur dan komisaris }}{\text { jumlah saham yang beredar }} \%
$$

\subsection{Metode Analisis Data}

Analisis data merupakan salah satu kegiatan penelitian berupa proses penyusunan dan pengolahan data guna menafsirkan data yang diperoleh. Penelitian ini bertujuan untuk menguji apakah ROA berpengaruh terhadap nilai peusahaan, serta untuk menguji apakah kepemilikan manajerial mempunyai pengaruh terhadap hubungan antara ROA dan nilai perusahaan. Untuk itu akan digunakan teknik analisis regresi linear sederhana. Sebelum analisis ini dilakukan, terlebih dahulu perlu dilakukan uji asumsi klasik untuk menghasilkan nilai parameter model penduga yang sah. Nilai tersebut akan terpenuhi jika hasil uji asumsi klasiknya memenuhi asumsi normalitas, serta tidak terjadi heteroskedastisitas, autokorelasi, dan multikolinearitas.

\subsection{Analisis Statistik Deskriptif}

Menurut Ghozali (2016 : 19), Statistik deskriptif merupakan gambaran atau deskripsi suatu data yang dilihat dari nilai rata-rata (mean), standar deviasi, maksimum, minimum, dan variabel yang diteliti. Statistik deskriptif mendeskripsikan data menjadi sebuah informasi yang lebih jelas dan mudah dipahami. Statistik deskriptif digunakan untuk mengembangkan profil perusahaan yang menjadi sampel statistik deskriptif berhubungan dengan pengumpulan dan peningkatan data, serta penyajian hasil peningkatan tersebut. 


\subsection{Analisis Regresi Data Panel}

Penelitian ini menggunakan analisis regresi data panel. Data panel adalah gabungan antara data time series dan cross section. Data time series adalah kumpulan data pada periode waktu tertentu yang dapat menggambarkan karakteristik objek penelitian, sedangkan cross section adalah kumpulan data dari waktu ke watu yang menggambarkan suatu kejadian tertentu.

\subsection{Pemilihan Model Regresi}

Menurut Widarjono (2007 : 251) untuk mengestimasi parameter model dengan data panel terdapat 3 (tiga) teknik yang ditawarkan, yaitu :

1. Model Common Effect. Teknik ini merupakan teknik yang paling sederhana untuk mengestimasi parameter data panel, yaitu dengan mengkombinasikan data cross section dan time series sebagai satu kesatuan tanpa melihat adanya perbedaan waktu dan individu. Pendekatan yang dipakai dalam model ini adalah metode Ordinary Least Square (OLS).

2. Model Fixed Effect. Teknik ini mengestimasi data panel dengan menggunakan variabel dummy untuk menangkap adanya perbedaan intersep. Pendekatan ini didasarkan adanya perbedaan intersep antara perusahaan. tetapi intersepnya sama antar waktu. Model ini juga mengasumsikan bahwa slope tetap antar perusahaan dan antar waktu. Pendekatan yang digunakan dalam model ini adalah metode Least Square Dummy Variable (LSDV).

3. Model Random Effect. Teknik ini mengestimasi data panel dimana variabel gangguan mungkin saling berhubungan antar waktu dan individu. Perbedaan antar individu dan antar waktu diakomodasi lewat error. Karena adanya korelasi antar variabel gangguan maka metode OLS tidak bisa digunakan, sehingga model random effect menggunakan Generalized Least Square (GLS).

\subsection{Analisis Model Data Panel}

\section{Uji Chow}

Uji chow merupakan uji yang dilakukan untuk menentukan antara model common effect dengan fixed effect yang paling tepat digunakan dalam mengestimasi data panel penelitian. Pengambilan keputusan yang dilakukan : 
a. Jika nilai prob $\mathrm{F}$. $<0,05$ maka $\mathrm{H}_{0}$ ditolak atau memilih fixed effect daripada common effect.

b. Jika nilai prob $\mathrm{F}$. $>0,05$ maka $\mathrm{H}_{0}$ diterima atau memilih common effect daripada fixed effect.

\section{Uji Hausman}

Uji hausman merupakan uji yang dilakukan untuk memilih apakah model fixed effect atau random effect yang paling tepat digunakan dalam penelitian. Pengambilan keputusan yang dilakukan :

c. Jika nilai chi-square hitung $>$ chi-square atau nilai probabilitas chi-square $<0,05$, maka $\mathrm{H}_{0}$ ditolak dan memilih fixed effect daripada random effect.

d. Jika nilai chi-squares hitung <chi-squares tabel atau nilai probabilitas chisquares $>0,05$, maka $\mathrm{H}_{0}$ diterima dan memilih random effect daripada fixed effect.

\section{Uji Lagrange Multiplier (LM)}

Uji Lagrange Multiplier adalah uji yang dilakukan untuk mengetahui apakah model random effect lebih baik daripada metode common effect (OLS). Pengambilan keputusan yang dilakukan :

e. Jika nilai $\mathrm{p}$ value $<0,05$ maka $\mathrm{H}_{0}$ ditolak dan memilih random effect daripada menggunakan common effect.

f. Jika nilai $\mathrm{p}$ value $>0,05$ maka tidak menolak $\mathrm{H}_{0}$ dan memilih common effect daripada menggunakan fixed effect.

\section{Uji Hipotesis}

Uji hipotesis dalam penelitian ini dilakukan dengan cara sebagai berikut :

\section{Analisis Regresi Linier Berganda}


Analisis kuantitatif yang digunakan pada penelitian ini adalah analisis regresi. Analisis regresi menurut Ghozali (2016 : 94) adalah mengukur kekuatan hubungan antara dua variabel atau lebih dan menunjukkan arah hubungan antara variabel dependen dengan variabel independen. Alasan penggunaan analisis regresi dikarenakan analisis ini dapat menyimpulkan penelitian dengan memperhitungkan faktor kesahihan dan statistik dapat bekerja dengan angka-angka yang bersifat objektif dan universal untuk semua bidang penelitian. Analisis regresi linear berganda merupakan hubungan secara linear antara dua atau lebih variabel, apakah masing-masing variabel berhubungan positif atau negatif dan memprediksi nilai variabel mengalami kenaikan atau penurunan. Model pengujian hipotesis dalam penelitian ini adalah dengan menggunakan analisis regresi linear berganda dengan perangkat lunak statistik yaitu EViews 9. Rumus yang digunakan dalam analisis regresi linear berganda sebagai berikut

\section{Tobin's $Q=\mathbf{a}+\mathrm{b}_{1} \mathbf{R O A}+\mathrm{e}$}

Keterangan :

Tobin's $Q \quad=$ Nilai Perusahaan

a $\quad=$ Konstanta

$\mathrm{b}_{1}, \mathrm{~b}_{2}, \mathrm{~b}_{3} \quad=$ Koefisien Regresi

ROA $=$ Variabel ROA

e Error

\section{Uji Koefisien Determinasi $\left(\mathbf{R}^{2}\right)$}

Koefisien determinasi $\left(\mathrm{R}^{2}\right)$ pada intinya mengukur seberapa jauh kemampuan model dalam menerangkan variabel-variabel dependen. Nilai koefisien determinasi berada di antara nol dan satu. Nilai $\mathrm{R}^{2}$ yang lebih kecil berarti kemampuan variabelvariabel independen dalam menjelaskan variabel dependen amat terbatas. Nilai yang mendekati satu berarti variabel-variabel independen memberikan hampir semua informasi yang dibutuhkan untuk memprediksi variabel-variabel dependen (Ghozali, 2016 : 95).

Pada data time series biasanya mempunyai nilai koefisien determinasi yang cukup tinggi. Adapun kelemahannya yaitu adanya bias terhadap jumlah variabel independen yang dimasukkan dalam model. Setiap tambahan satu variabel independen, 
maka $\mathrm{R}^{2}$ akan meningkat tanpa peduli apakah variabel tersebut berpengaruh signifikan terhadap variabel dependen.

\section{Uji t (Uji Parameter Individual)}

Menurut Ghozali (2016 : 97), uji t pada dasarnya menunjukkan seberapa jauh pengaruh satu variabel penjelas atau independen secara individual dalam menerangkan variasi variabel dependen. Pengujian untuk mengetahui kemampuan masing-masing variabel independen dalam menjelaskan perilaku variabel dengan uji statistik $\mathrm{t}$ menggunakan signifikansi level 0,05 ( $\alpha=5 \%)$. Ketentuan menganalisa adalah sebagai berikut :

1. Jika signifikansi > 0,05 berarti bahwa secara parsial variabel independen tidak mempunyai pengaruh signifikan terhadap variabel dependen.

2. Jika signifikansi $<0,05$ dari hasil t-hitung bernilai positif berarti bahwa secara parsal variabel independen berpengaruh signifikan terhadap variabel dependen.

\section{Analisis Regresi Moderasi (Moderated Regression Analysis)}

Menurut Ghozali (2016), tujuan analisi ini adalah untuk mengetahui apakah variabel moderating akan memperkuat atau memperlemah hubungan antara variabel independen dan variabel dependen. Dalam penelitian ini akan digunakan uji MRA, hipotesis moderating diterima jika variabel moderasi KM (ROA-KM) mempunyai pengaruh signifikan terhadap Tobin's $Q$. Rumus yang digunakan dalam analisis regresi moderasi sebagai berikut :

\section{Tobin's $Q=\mathrm{a}+\mathrm{b}_{1}$ ROA $+\mathrm{b}_{2} \mathrm{KM}+\mathrm{b}_{3}$ ROE.KM + e}

Keterangan :

Tobin's $Q=$ Nilai Perusahaan

a $\quad=$ Konstanta

$b_{1}, b_{2}, b_{3} \quad=$ Koefisien Regresi

ROA = Variabel ROA

$\mathrm{KM}=$ Variabel Kepemilikan Manajerial

ROE.KM = Variabel Interaksi ROE dengan KM (Moderasi KM)

$\mathrm{e}=$ Error 


\section{HASIL DAN PEMBAHASAN}

Adapun perhitungan sampel yang akan digunakan dalam penelitian ini adalah sebagai berikut :

\section{Tabel 4.1}

\section{Perhitungan Sampel Penelitian}

\begin{tabular}{|l|c|}
\hline \multicolumn{1}{|c|}{ Kriteria Sampel } & Jumlah Perusahaan \\
\hline $\begin{array}{l}\text { Perusahaan yang termasuk dalam sektor manufaktur yang } \\
\text { terdaftar di Bursa Efek Indonesia (BEI) }\end{array}$ \\
\hline $\begin{array}{l}\text { Perusahaan yang tidak menerbitkan laporan tahunan (annual } \\
\text { report) dan data keuangan yang lengkap selama tahun penelitian }\end{array}$ \\
\hline Perusahaan yang mengalami kerugian selama tahun pengamatan \\
\hline $\begin{array}{l}\text { Perusahaan yang tidak memiliki data keuangan yang berkaitan } \\
\text { dengan variabel penelitian }\end{array}$ \\
\hline $\begin{array}{l}\text { Perusahaan yang tidak menggunakan satuan nilai rupiah dalam } \\
\text { laporan keuangannya }\end{array}$ \\
\hline Sampel (Perusahaan) & $(23)$ \\
\hline Total observasi (data) selama 3 tahun periode penelitian & 159 \\
\hline
\end{tabular}

Berdasarkan kriteria yang telah ditetapkan diatas, diperoleh 61 perusahaan yang memenuhi kriteria yang ditentukan sehingga dapat dijadikan sebagai sampel dalam penelitian ini selama 2 tahun pengamatan. Dengan metode purposive sampling maka penelitian ini memiliki 122 data observasi. Sampel perusahaan lampiran 1.

\section{HASIL PENELITIAN}

\subsection{Statistik Deskriptif}

Tujuan penggunaannya adalah untuk mengetahui gambaran umum mengenai data penelitian dan hubungan yang ada antara variabel-variabel yang digunakan dalam penelitian. Statistik deskriptif dalam penelitian ini pada dasarnya merupakan proses transformasi data penelitian dalam bentuk tabulasi yang menyajikan ringkasan, pengukuran atau penyusunan data dalam bentuk tabel numeric dan grafik sehingga mudah dipahami dan diinterpretasikan (Indriantoro, $2002: 170$ ).

\section{Analisis Regresi Linear Berganda}

Analisis regresi linear berganda dimaksudkan untuk menguji seberapa jauh pengaruh variabel independen terhada variabel dependen. 
Tabel 4.12.

Hasil Persamaan Regresi Linear Berganda Tanpa Moderasi

\begin{tabular}{ccccc}
\hline Variabel & Coefficient & Std. Error & t-Statistic & Prob. \\
\hline \hline C & $-0,143405$ & 0,146393 & $-0,979595$ & 0,3293 \\
ROA & 19,86709 & 1,185086 & 16,76426 & 0,0000 \\
\hline \hline
\end{tabular}

Sumber : Hasil Pengolahan Eviews 9

Berdasarkan hasil diatas, didapat persamaan regresi linear berganda sebagai berikut :

$$
\text { Tobins' } Q=-0,143405+19,86709 R O A+e
$$

Keterangan :

Tobins'Q : Proksi dari nilai perusahaan

ROA : Return on Asset

E : Error, tingkat kesalahan

Berdasarkan persamaan regresi linear berganda diatas dapat dianalisis pengaruh masing-masing variabel independen terhadap variabel dependen sebagai berikut :

1. Konstanta $\alpha$ sebesar $-0,143405$ menyatakan bahwa jika nilai dari return on asset (X) adalah konstan maka besarnya nilai perusahaan sebesar -0,143405.

2. Nilai koefisien regresi X mempunyai hubungan positif 19,86709 untuk return on asset, yang artinya setiap perubahan 1 nilai return on aset maka besarnya nilai perusahaan akan mengalami kenaikan sebesar 19,86709 satuan dan faktor lain dianggap tetap. Kesimpulannya adalah apabila nilai ROA naik maka Tobins ' $Q$ juga mengalami kenaikan.

Tabel 4.13.

\section{Hasil Persamaan Regresi Linear Berganda dengan Moderasi}

\begin{tabular}{ccccc}
\hline Variabel & Coefficient & Std. Error & t-Statistic & Prob. \\
\hline \hline C & $-0,148433$ & 0,154917 & $-0,958144$ & 0,3399 \\
ROA & 20,10312 & 1,216268 & 16,52854 & 0,0000 \\
KM & 0,006305 & 0,010328 & 0,610494 & 0,5427 \\
ROA_KM & $-0,124412$ & 0,118490 & $-1,049975$ & 0,2959 \\
\hline \hline
\end{tabular}

Sumber : Hasil Pengolahan Eviews 9

Berdasarkan hasil diatas, didapat persamaan regresi linear berganda sebagai berikut : 
Tobins' $Q=-0,148433+20,10312 R O A+0.006305 K M-0,124412 R O A x K M+e$

Keterangan :

Tobins'Q : Proksi dari nilai perusahaan

KM : Kepemilikan Manajerial

ROA : Return on Asset

E : Error, tingkat kesalahan

\subsection{Hasil Penelitian}

\section{Pengaruh Return on Asset terhadap Nilai Perusahaan}

Hasil pengujian analisis menunjukkan bahwa nilai signifikansi uji parsial dari ROA (X) sebesar 0,0000 < 0,05 dengan nilai coefficient sebesar 19,86709. Maka hasil tersebut menunjukkan bahwa $\mathrm{H}_{1}$ dapat diterima yang artinya ROA berpengaruh positif signifikan terhadap nilai perusahaan. Nilai ROA yang tinggi menunjukkan kinerja yang semakin baik, karena tingkat pengembalian yang semakin besar. Tinggi rendahnya ROA tergantung pada pengelolaan aset perusahaan oleh manajemen yang menggambarkan efisiensi dari opersional perusahaan, semakin tinggi ROA semakin efisien perusahaan. Hal ini menunjukkan semakin efisien perusahaan maka semakin tinggi pula kemampuan perusahaan dalam menghasilkan laba bagi perusahaan, sehingga akan berdampak pada meningkatnya nilai perusahaan.

Hasil ini mendukung penelitian yang dilakukan Imron, Hidayat dan Alliyah (2013), Hermuningsih (2013), Kusumawati dan Rosady (2018), dan Sari, Mardani dan Salim (2016) yang menunjukkan bahwa ROA berpengaruh positif signifikan terhadap nilai perusahaan.

\section{Pengaruh Return on Asset dengan Kepemilikan Manajerial Sebagai Variabel Moderasi terhadap Nilai Perusahaan}

Hasil uji analisis menunjukkan bahwa nilai signifikansi t-MRA sebesar 0,2959 $>$ 0,05 dengan nilai coefficient sebesar -0,124412. Artinya bahwa kepemilikan manajerial tidak dapat memoderasi atau tidak berpengaruh terhadap hubungan antara ROA dengan nilai perusahaan. hal ini mungkin dikarenakan oleh struktur kepemilikan saham manajerial pada perusahaan manufaktur di Indonesia masih cenderung sangat rendah dan kepemilikan saham didominasi oleh keluarga ataupun perusahaan lain. 
Rendahnya kepemilikan saham oleh manajemen mengakibatkan pihak manajemen belum merasa ikut memiliki perusahaan karena belum dapat menikmati keuntungan yang didapat oleh perusahaan sehingga pihak manajemen tidak termotivasi untuk memaksimalkan utilitasnya dengan baik. Hasil ini memperkuat kesimpulan penelitian yang dilakukan oleh Saragih (2018).

\section{SIMPULAN DAN SARAN}

\subsection{Simpulan}

Berdasarkan hasil analisis data penelitian dan pembahasan yang telah dilakukan oleh peneliti, maka dapat diambil kesimpulan sebagai berikut :

1. Variabel Return on Asset berpengaruh positif signifikan terhadap nilai perusahaan. karena tingkat signifikansi ROA kurang dari 0,05 maka pengaruh ROA tehadap nilai perusahaan dinyatakan signifikan. Dengan demikian hipotesis 1 dalam penelitian yang menyatakan "Return on Asset berpengaruh positif terhadap nilai perusahaan" dapat diterima. Hal ini mencermikan semakin tinggi nilai ROA maka semakin tinggi pula kemampuan perusahaan dalam menghasilkan laba bagi perusahaan, sehingga akan berdampak pada tingginya nilai perusahaan. banyak faktor dari dalam maupun luar ekonomi yang mempengaruhi kinerja keuangan perusahaan membuat perusahaan harus mampu menyusun strategi bisnis yang baik agar dapat mempertahankan kinerja keuangan dan nilai perusahaan.

2. Variabel kepemilikan manajerial tidak berpengaruh signifikan atau memperlemah terhadap hubungan antara Return on Asset dengan nilai perusahaan. Dengan demikian hipotesis 2 dalam penelitian ini menyatakan "Return on Asset berpengaruh terhadap nilai perusahaan dengan kepemilikian manajerial sebagai variabel moderasi" tidak diterima. Hal ini diduga karena struktur kepemilikan saham manajerial oleh perusahaan di Indonesia masih kecil dan masih didominasi oleh keluarga ataupun perusahaan lain.

\subsection{Saran}

Berdasarkan kesimpulan dan hasil penelitian tersebut, maka dapat di kemukakan beberapa saran yang dapat digunakan untuk penelitian selanjutnya sebagai berikut : 
1. Diharapkan untuk penelitian selanjutnya sebaiknya menambah faktor lainnya yang dapat mempengaruhi nilai perusahaan agar hasil dari penelitian semakin berkembang.

2. Penelitian selanjutnya diharapkan dapat memeperluas sampel penelitian dengan manambah periode penelitian atau menambah sektor perusahaan yang diteliti sehingga terdapat perbedaan hasil yang akan diperoleh.

3. Perusahaan diharapkan dapat menerapkan startegi bisnis yang baik sehingga dapat menstabilkan kinerja perusahaannya dan dapat mempertahankan nilai perusahaannya di mata para investor.

\section{Keterbatasan dan Pengembangan Penelitian Selanjutnya}

Keterbatasan penulis selama melakukan penelitian ini yaitu kurangnya referensi jurnal terkait dengan variabel moderasi terutama dalam hal jurnal internasional. 


\section{DAFTAR PUSTAKA}

Attar, D., Islahuddin, dan Shabri, M. 2014. Pengaruh Penerapan Manajemen Risiko terhadap Kinerja Keuangan Perbankan yang Terdaftar di Bursa Efek Indonesia. Jurnal Akuntansi. 3(1), 10-20.

Boediono, Gideon SB. 2005. Kualitas Laba : Studi Pengaruh Mekanisme Corporate Governance dan Dampak Manajemen Laba dengan Menggunakan Analisis Jalur. Simposium Nasional Akuntansi VIII, Solo, 15-16 September 2005: 172194. Ikatan Akuntan Indonesia.

Chun, S.E., dan Lee, M. H. 2017. Corporate Ownership Structure and Risk Taking Evidence From Japan. Journal of Governance and Regulation. Volume 6 Issue 4, 39-52.

Darmawati, D. K., dan Rahayu, R.G. 2004. Hubungan Corporate Governance dan Kinerja Perusahaan. Simposium Nasional Akuntansi VII. Denpasar.

Erdianty, Ratri Werdi dan Imam Bintoro. 2014. Pengaruh Kinerja keuangan Terhadap Nilai Perusahaan dengan Corporate Social Responsibility dan Good Corporate Governance sebagai Variabel Pemoderasi (Studi pada Perusahaan Manufaktur yang Terdaftar di Bursa Efek Indonesia Periode 2010-2014). Jurnal Ekonomi dan Bisnis. Hal. 376-396. Universitas Muhammadiyah Yogyakarta. Yogyakarta.

Fahlenbrach, R., dan Stulz, R. M. 2009. Managerial Ownership Dynamics and Firm Value. Journal of Financial Economics 92. Page 342-361. Elsevier.

FCGI. 2001. Corporate Governance : Tata Kelola Perusahaan. Edisi Ketiga, Jakarta.

Ghozali, Imam. 2016. Aplikasi Analisis Multivariate Dengan Program IBM SPSS 19. Semarang : Universitas Diponegoro.

Hermuningsih, S. 2013. Pengaruh Profitabilitas, Size terhadap Nilai Perusahaan dengan Struktur Modal sebagai Variabel Intervening. Jurnal Siasat Bisnis, Vol.16, No. 2, Hal. 232-242.

http://www.idx.co.id

Ikatan Akuntansi Indonesia (IAI). 2007. Standar Akuntansi Keuangan 2007. Salemba Empat : Jakarta.

Imron, Galih Syaiful, Riskin Hidayat, dan Siti Alliyah. 2013. Pengaruh Kinerja Keuangan dan Ukuran Perusahaan terhadap Nilai Perusahaan dengan Good 
Corporate Governance sebagai Variabel Moderasi. Potensio Vol. 18, No.2, Hal. 82-93.

Indriantoro, Nur dan Supomo, B. 2002. Metodologi Penelitian Bisnis Untuk Akuntansi dan Manajemen. Yogyakarta : BPFE.

Ju Chen, Li dan Yu Chen, Shun. 2011. The Influence of Profitability on Firm Value With Capital Structure as The Mediator and Firm Size and Industry as Moderators. Investment Management and Financial Innovations, Vol. 8, Issue 3.

Komang, I dan Putu Wirawati. 2013. Pengaruh Kepemilikan Manajerial Terhadap Hubungan antara Kinerja dengan Nilai Perusahaan Studi pada Bursa Efek Indonesia periode 2009-2011. Jurnal Akuntansi. Universitas Udayana. Denpasar.

Kusumawati, Rita dan Irham Rosady. 2018. Pengaruh Struktur Modal dan Profitabilitas terhadap Nilai Perusahaan dengan Kepemilikan Manajerial sebagai Variabel Moderasi. Jurnal Manajemen Bisnis. Vol. 9 No. 2, Hal. 147160.

Mardiyanto, Handono. 2009. Intisari Manajemen Keuangan. Jakarta : Grasindo.

Muh, Arief Effendi. 2009. The Power of Good Corporate Governance: Teori dan Implementasi. Jakarta : Salemba Empat.

Mulyadi. 2007. Sisten Terpadu Pengelolaan Kinerja Personel Berbasis Balanced Scorecard. UPP STIM YKPN. Yogyakarta.

Mustafa, C. C., dan N. Handayani. 2014. Pengaruh Pengungkapan Corporate Social Responsibility Terhadap Kinerja Keuangan Perusahaan Manufaktur. Jurnal Ilmu \& Riset Akuntansi, Vol. 3, No. 6, Hal 1-16.

Nachrowi, D. 2006. Ekonometrika, untuk Analisis Ekonomi dan Keuangan. Cetakan Pertama. Jakarta : Lembaga Penerbit FE UI.

OECD. 2004. The OECD Principles of Corporate Governance. France : Organization for Economic Co-operation and Development (OECD) Publications Service.

Perdana, Ramadhan Sukma dan Raharja. 2014. Analisis Pengaruh Corporate Governance Terhadap Nilai Perusahaan. Diponegoro Journal of Accounting. Semarang : Universitas Diponegoro. 
Permata, D. N. I., Kusumawati, F., dan Suryawati, R. F. 2012. Pengaruh Penerapan Good Corporate Governance terhadap Kinerja Keuangan Perusahaan. Jurnal Infestasi Universitas Trunojoyo Madura, Vol. 8 No. 2.

Prasinta, D. 2012. Pengaruh Good Corporate Governance Terhadap Kinerja Keuangan. Accounting Analysis Journal 2(1), 4-17.

Prastyaningrum, 2008 dalam Shanty, 2014

Randy, Vincentius dan Juniarti. 2013. Pengaruh Penerapan Good Corporate Governance Terhadap Nilai Perusahaan yang Terdaftar di BEI 2007-2011. Business Accounting Review, Vol. 1 No. 2, 306-308.

Rudianto. 2013. Akuntansi Manajemen Informasi untuk Pengambilan Keputusan Strategis. Jakarta : Erlangga.

Sanusi, Anwar. 2014. Metodologi Penelitian Bisnis. Jakarta : Salemba Empat.

Saragih, Roy Ariando. 2018. Pengaruh Growth Opportunity, Profitabilitas, dan Struktur Modal Terhadap Nilai Perusahaan dengan Good Corporate Governance sebagai Variabel Moderasi pada Perusahaan Manufaktur Sektor Tekstil dan Garmen di Bursa Efek Indonesia Periode 2012-2016. JOM FEB. Vol. 1 Edisi 1. Universitas Riau. Pekanbaru.

Sari, Auliyah Palupi Putri Indra, Ronny Malavia Mardani, dan M. Agus Salim. 2018.

Pengaruh Kinerja Keuangan Terhadap Nilai Perusahaan Dengan Pengungkapan CSR dan GCG Sebagai Variabel Pemoderasi. E-Jurnal Riset Manajemen. Universitas Islam Malang. Malang.

Sari, D A. 2015. Kinerja Keuangan, Corporate Social Responsibility, Good Corporate Governance dan Nilai Perusahaan. Simposium Nasional Akuntansi XIII. Purwokerto.

Sekaran, Uma. 2011. Research Methods For Bussines. Buku 1, Edisi ke-4. Salemba Empat : California.

Sucuahi, W., dan Cambarihan, J. M. 2016. Influence of Profitability to the Firm Value of Diversified Companies in the Philippines. Accounting and Finance Research, Vol. 5 Issue 2, Page 149-153.

Sudiyanto, Bambang dan Elen Puspitasari. 2010. Tobin's Q dan Altman Z-Score Sebagai Indikator Pengukur Kinerja Perusahaan. Kajian Akuntansi, Februari 2010, Hal. 9-21, Vol. 2 No. 1. 
Sugiyono. 2010. Metode Penelitian Bisnis. Bandung : CV Alfabeta.

Sugiyono. 2017. Metode Penelitian Kuantitatif, Kualitatif, dan R\&D. Bandung : CV Alfabeta.

Sujoko, dan Soebintoro, U. 2007. Pengaruh Faktor Kepemilikan, Leverage, Faktor Intern, dan Faktor Ekstern terhadap Nilai Perusahaan (Studi Empiris pada Perusahaan Manufaktur dan Non Manufaktur di Bursa Efek Jakarta). Jurnal Manajemen dan Kewirausahaan. Vol. 9(1), Hal. 41-49.

Sunyoto, Danang. 2013. Metodologi Penelitian Akuntansi. Bandung : PT Refika Aditama Anggota Ikapi.

Syamsuddin, Lukman. 2013. Manajemen Keuangan Perusahaan: Konsep Aplikasi dalam Perencanaan, Pengawasan dan Pengambilan Keputusan. Edisi Baru. Jakarta : PT. Raja Grafindo Persada.

UU No.40 Tahun 2007 tentang Perseroan Terbatas. (n.d).

Widarjono, Agus. 2007. Ekonometrika : Teori dan Aplikasi Untuk Ekonomi dan Bisnis. Edisi Kedua. Yogyakarta : Ekonisia FE Universitas Islam Indonesia. 